\title{
Reaction Mechanism and Mechanical Property Improvement of Poly(Lactic Acid) Reactive Blending with Epoxy Resin
}

\author{
Krittameth Kiattipornpithak ${ }^{1}$, Nanthicha Thajai ${ }^{2}$, Thidarat Kanthiya ${ }^{1}$, Pornchai Rachtanapun ${ }^{1,3,4} \mathbb{1}$,

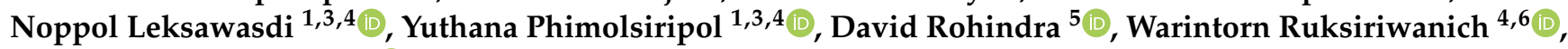 \\ Sarana Rose Sommano ${ }^{4,7}$ and Kittisak Jantanasakulwong ${ }^{1,3,4, *}$
}

1 Faculty of Agro-Industry, Chiang Mai University, Mae-Hea, Mueang, Chiang Mai 50100, Thailand; first200294@gmail.com (K.K.); thidaratkanthiya05@gmail.com (T.K.); Pornchai.r@cmu.ac.th (P.R.); noppol@hotmail.com (N.L.); yuthana.p@cmu.ac.th (Y.P.)

2 Faculty of Science, Chiang Mai University, Chiang Mai 50200, Thailand; nanthicha581@gmail.com

3 Cluster of Agro Bio-Circular-Green Industry, Chiang Mai University, Chiang Mai 50100, Thailand

4 Center of Excellence in Materials Science and Technology, Faculty of Science, Chiang Mai University, Chiang Mai 50200, Thailand; warintorn.ruksiri@cmu.ac.th (W.R.); sarana.s@cmu.ac.th (S.R.S.)

5 School of Biological and Chemical Sciences, Faculty of Science, Technology and Environment, The University of the South Pacific, Laucala Bay Road, Suva, Fiji; david.rohindra@usp.ac.fj

6 Department of Pharmaceutical Sciences, Faculty of Pharmacy, Chiang Mai University, Mae-Hia, Muang, Chiang Mai 50100, Thailand

Citation: Kiattipornpithak, K.;

Thajai, N.; Kanthiya, T.; Rachtanapun, P.; Leksawasdi, N.; Phimolsiripol, Y.; Rohindra, D.; Ruksiriwanich, W.; Sommano, S.R.; Jantanasakulwong, K. Reaction Mechanism and Mechanical Property Improvement of Poly(Lactic Acid) Reactive Blending with Epoxy Resin. Polymers 2021, 13, 2429. https://doi.org/10.3390/polym 13152429

Academic Editor: Keon-Soo Jang

Received: 3 July 2021

Accepted: 18 July 2021

Published: 23 July 2021

Publisher's Note: MDPI stays neutral with regard to jurisdictional claims in published maps and institutional affiliations.

Copyright: ( $\odot 2021$ by the authors. Licensee MDPI, Basel, Switzerland. This article is an open access article distributed under the terms and conditions of the Creative Commons Attribution (CC BY) license (https:// creativecommons.org/licenses/by/ $4.0 /)$.
7 Plant Bioactive Compound Laboratory (BAC), Department of Plant and Soil Sciences, Faculty of Agriculture, Chiang Mai University, Chiang Mai 50200, Thailand

* Correspondence: jantanasakulwong.k@gmail.com; Tel.: +66-(0)-5394-8274; Fax: +66-(0)-5394-8230

Abstract: Polylactic acid (PLA) was melt-blended with epoxy resin to study the effects of the reaction on the mechanical and thermal properties of the PLA. The addition of $0.5 \%(\mathrm{wt} / \mathrm{wt})$ epoxy to PLA increased the maximum tensile strength of PLA ( $57.5 \mathrm{MPa}$ ) to $67 \mathrm{MPa}$, whereas the $20 \%$ epoxy improved the elongation at break to $12 \%$, due to crosslinking caused by the epoxy reaction. The morphology of the PLA/epoxy blends showed epoxy nanoparticle dispersion in the PLA matrix that presented a smooth fracture surface with a high epoxy content. The glass transition temperature of PLA decreased with an increasing epoxy content owing to the partial miscibility between PLA and the epoxy resin. The Vicat softening temperature of the PLA was $59^{\circ} \mathrm{C}$ and increased to $64.6{ }^{\circ} \mathrm{C}$ for $0.5 \%$ epoxy. NMR confirmed the reaction between the - $\mathrm{COOH}$ groups of PLA and the epoxy groups of the epoxy resin. This reaction, and partial miscibility of the PLA/epoxy blend, improved the interfacial crosslinking, morphology, thermal properties, and mechanical properties of the blends.

Keywords: toughness; thermal properties; interfacial crosslink; reaction

\section{Introduction}

Biodegradable polymers have attracted considerable attention in recent years owing to their environmental effects. Petroleum plastics are being replaced by renewable, eco-friendly materials. Biodegradable polymers, such as PLA [1], polybutylene succinate (PBS) [2], thermoplastic starch (TPS) [3], starch [4], polysaccharides [5], carboxymethyl bacterial cellulose [6], and pectin $[7,8]$ have been widely studied. PLA is an eco-friendly polymer as it is synthesized using lactic acid extracted from natural sources. PLA is a typical biodegradable plastic [9] that can be used to replace commercial single-use plastics [10,11]. PLA is one of most promising candidates to replace petroleum plastic as the monomers are produced from renewable feedstock. PLA is synthesized from lactic acid using ring opening polymerization, polycondensation, and enzymatic polymerization [12]. PLA is a thermoplastic material, with high-mechanical properties, biodegradability, biocompatibility, and transparency. However, PLA has disadvantages such as brittleness, heat resistance, and barrier properties [13]. Property improvement of PLA has been investigated by several researchers [14-16]. Several 
studies have investigated the improvement of PLA brittleness and flexibility [14]. Polymer blending and co-polymerization are two methods that can be used to improve polymer mechanical properties $[17,18]$. Notably, PLA has been previously reported as a coating material to improve mechanical properties and water resistance of TPS [19].

Epoxy resin is a reactive polymer that contains epoxide groups in the structure, which are used to crosslink with variant functional groups such as amides and carboxylic [20]. Bisphenol A based epoxy resin is the common epoxy resin, which is derived by the reaction of thiol, alcohols, and amines with epichlorohydrin [20]. Epoxy resin is a substance that is used to improve PLA owing to its increased toughness, low shrinkage, corrosion resistance, and improved heat resistance [21-24]. Epoxy resins have epoxy groups that react with amines [25], carboxylic acids, and hydroxyl groups [26]. Epoxy interacts with some thermoplastics, such as polycarbonate [27], polyamine [28], and PLA [29]. Epoxy resin acts as a bridge to connect the polymer on both reactive sides, thus allowing the epoxy to bind different polymers [26]. In addition, chemical reactions influence the morphology, melting, and crystallization behaviors that lead to property changes [10]. Nevertheless, a high amount of epoxy resin creates a highly networked structure, resulting in a thermoset polymer. Incorporation of epoxy resin into PLA increased molecular weight, and networked and branched structures which slowed down the hydrolytic degradation of PLA by approximately $130 \%$ compared to pure PLA [30]. Epoxy resin was used as a compatibilizer to improve compatibility of the PLA/polyamide blend [31]. Reactive blending of epoxy resin and PLA increased mechanical properties, melt strength, torque, toughness, and melt viscosity, but decreased crystallinity of PLA $[32,33]$. These improvements were due to a reaction between - $\mathrm{COOH}$ end groups of PLA and epoxy groups of epoxy resin [32,33]. However, the reaction mechanism, plasticizing effect, and morphology of epoxy resin blending with PLA have not been reported.

Therefore, in this study, the effect of epoxy resin on PLA blending was investigated. PLA was melt-blended with $0-20 \%$ epoxy at $170{ }^{\circ} \mathrm{C}$ for $10 \mathrm{~min}$. Mechanical properties, morphology, thermal properties, thermal stability, and the reaction mechanism were investigated.

\section{Materials and Methods}

\subsection{Materials}

Poly(lactic acid) (PLA) pellet (4032D, MW 100,000 g/mol, density $1.24 \mathrm{~g} / \mathrm{cc}$, MFI $=7 \mathrm{~g} / 10 \mathrm{~min}$ at $210^{\circ} \mathrm{C}$, NatureWorks LLC., Minnetonka, MN, USA) was purchased from PTT Global Chemical Pub Co., Ltd., Bangkok, Thailand. Diglycidyl ether of bisphenol A epoxy resin (grade 0302, liquid state) was purchased from EASY Resin Co., Ltd., Nonthaburi, Thailand.

\subsection{Sample Preparation}

PLA was blended with epoxy resin using a two-roll mill machine (Model PII140, Pirom-Olarn, Bangkok, Thailand) at $170{ }^{\circ} \mathrm{C}$ for $10 \mathrm{~min}$, and then compressed into sheets by a hot compress at $170{ }^{\circ} \mathrm{C}$ for $10 \mathrm{~min}$, followed by quenching at $10-25^{\circ} \mathrm{C}$. PLA was blended with $0.5-20 \%(\mathrm{wt} / \mathrm{wt})$, a monomer of epoxy resin without a hardener to study the effects of the epoxy content. Code name and composition of the sample are shown in Table 1.

Table 1. Code name and composition of PLA and epoxy resin blend.

\begin{tabular}{ccc}
\hline Sample & PLA & Epoxy Resin \\
\hline PLA & 100 & 0 \\
PLA/epoxy0.5 & 99.5 & 0.5 \\
PLA/epoxy1 & 99 & 1 \\
PLA/epoxy2 & 98 & 2 \\
PLA/epoxy5 & 95 & 5 \\
PLA/epoxy10 & 90 & 10 \\
PLA/epoxy20 & 80 & 20 \\
\hline
\end{tabular}




\subsection{Tensile Properties}

The tensile properties were measured following JISK-6251-7 using a tensile tester at a crosshead speed of $10 \mathrm{~mm} / \mathrm{min}$ with a gauge length of $10 \mathrm{~mm}$. Bone-shaped specimens of $30 \times 10 \times 0.2 \mathrm{~mm}$ (length $\times$ width $\times$ thickness) were prepared using compression molding at $170{ }^{\circ} \mathrm{C}$ for $5 \mathrm{~min}$.

\subsection{Scanning Electron Microscopy (SEM)}

Morphologies of the blended samples were characterized using SEM (JSM-5910LV JEOL Co., Ltd., Tokyo, Japan) at $15 \mathrm{kV}$. The samples were broken in liquid nitrogen, followed by the coating of the fracture surface with a thin layer of gold using sputtering (108 Auto/SE sputter coater, Cressington Co., Ltd., Watford, England).

\subsection{Differential Scanning Calorimetry (DSC)}

$$
\% X_{c}=\left(\frac{\Delta H_{m}-\Delta H_{c}}{H_{m}^{0}}\right) \times 100
$$

where $\Delta H_{m}$ and $\Delta H_{c}$ are the enthalpy of melting and cold crystallization, respectively. $\Delta H_{m}^{0}$ is the melting enthalpy of $100 \%$ PLA $(93.7 \mathrm{~J} / \mathrm{g})$ [34].

\subsection{Vicat Softening Temperature}

The samples with dimensions of $10 \mathrm{~mm} \times 10 \mathrm{~mm} \times 3 \mathrm{~mm}$ (width $\times$ length $\times$ thickness) were prepared using hot-compression molding at $170^{\circ} \mathrm{C}$ for $5 \mathrm{~min}$. The prepared samples were then tested by increasing the temperature until the flattened needle penetrated $1 \mathrm{~mm}$ into the surface using the ASTM D1525 standard. At least five specimens of each sample were tested.

\subsection{Nuclear Magnetic Resonance (NMR)}

The spectra were acquired using NMR (NEOTM $500 \mathrm{MHz}$, Bruker Co., Ltd., Boston, MA, USA). Samples were dissolved in a chloroform solvent (CDCL3) at $25 \mathrm{mg} / \mathrm{mL}$ before observation. Analysis of NMR intensities via different statistical models was evaluated using a custom-written Topspin 4.0.8 (Bruker BioSpin GmbH, Karlsruhe, Germany).

\subsection{Statistical Analysis}

The one-way ANOVA with the Statistical Package for the Social Sciences, SPSS Version 17 (SPSS, Armonk, NY, USA) was used to analyze the data. The differences found $(p<0.05)$ were evaluated using Duncan's test.

\section{Results and Discussion}

\subsection{Mechanical Properties}

PLA was melt-blended with epoxy resin $(0-20 \% w / w)$ to observe the effect of epoxy on the mechanical properties of the blends. The stress-strain curve, maximum tensile strength, and elongation at break are shown in Figure $1 \mathrm{a}, \mathrm{b}$. The maximum tensile strength of the neat PLA was $57.5 \mathrm{MPa}$, and the addition of $0.5 \%$ epoxy enhanced the maximum tensile strength to $66.9 \mathrm{MPa}$ due to crosslinking caused by the epoxy reaction. Increasing the epoxy content extended the elongation at break of the blends, as a high crosslinking inside the PLA phase led to the formation of a network structure [35]. The Young's modulus of PLA was $2.3 \mathrm{GPa}$, while PLA blend with epoxy $0.5,1,2,5,10$, and $20 \%$ were 1.6, 1.7, $1.5,1.6,1.2$, and $1.5 \mathrm{GPa}$, respectively. The epoxy resin reduced Young's modulus of PLA, owing to the partial miscibility between PLA and the epoxy [24]. The high amount of epoxy acted as a plasticizer for the PLA, thereby reducing Young's modulus and maximum tensile strength, and increasing the elongation at break, owing to its effect on the enhanced distance between the PLA molecules [29]. 

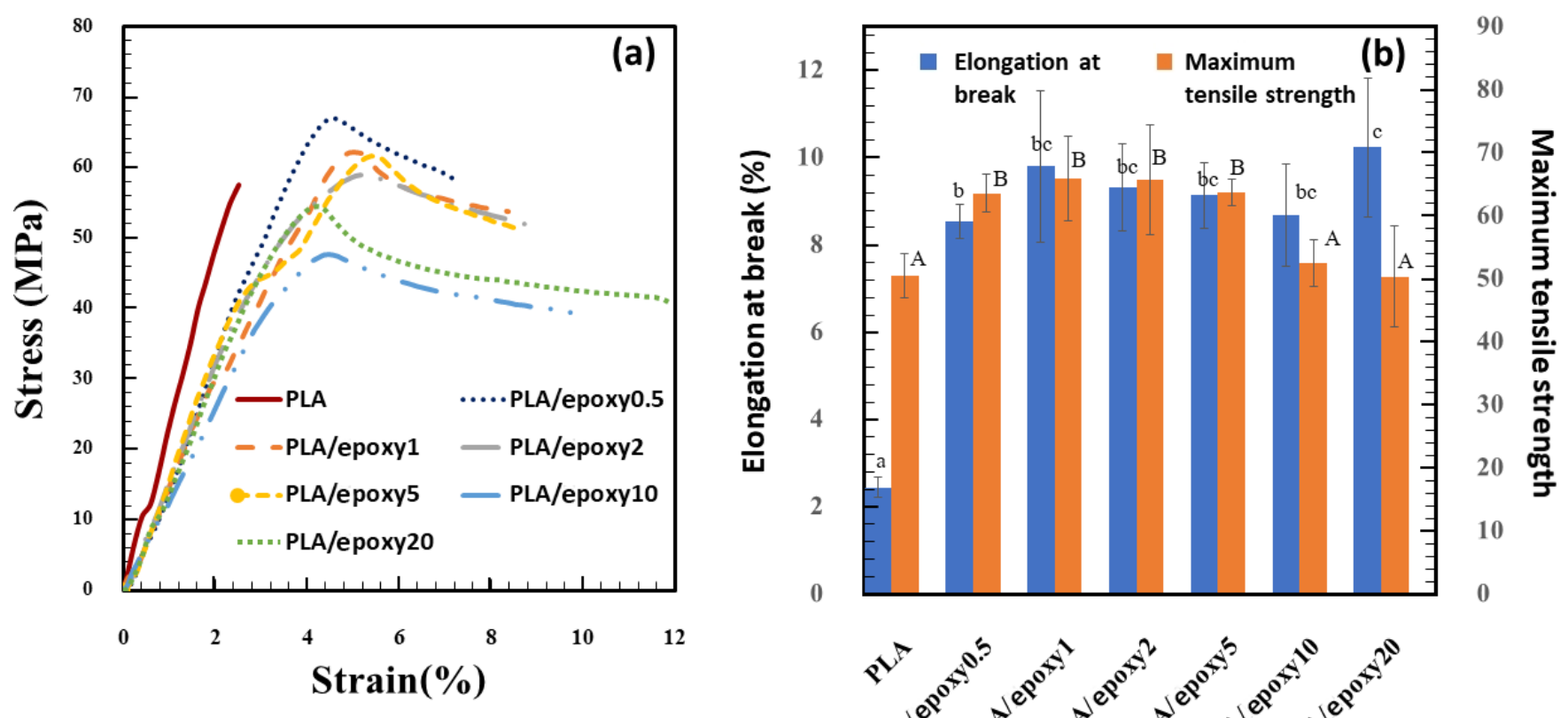

Figure 1. Tensile properties of PLA blend with 0-20\% epoxy (a) Stress-strain curve, and (b) Maximum tensile strength and elongation at break. The different of each lowercase and each uppercase letters indicate the mean values of the elongation at break and the maximum tensile strength differ significantly $(p<0.05)$, respectively.

\subsection{Morphology}

Figure 2 shows the morphology of the PLA blend with $0.5-20 \%$ epoxy resin. The PLA/epoxy0.5 blend exhibited small epoxy particles $(200 \mathrm{~nm})$ dispersed in the PLA matrix. Holes of the removed epoxy particles from the PLA matrix were also observed (Figure 2a). The formation of epoxy nanoparticles indicated a high compatibility between PLA and the epoxy. The PLA blend with 1-2\% epoxy exhibited fine epoxy nanoparticles distributed in the PLA matrix without the removal of the epoxy particles, whereas a high epoxy content $(5-20 \%)$ suggested nanoparticles that were smaller than those in the PLA/epoxy0.5 blend with a smooth fracture surface. This can be attributed to the high interfacial adhesion between PLA and the epoxy through the crosslinking interfacial reaction between PLA and the epoxy [24]. The small sizes of the epoxy particles and high interfacial adhesion resulted in the high transparency of the blend due to low light scattering [36].

\subsection{Differential Scanning Calorimetry (DSC)}

DSC curves were used to determine the effect of the epoxy resin on the thermal properties of the PLA/epoxy blends. The $T_{g}$ and $T_{m}$ were measured during the second heating scan. Figure 3 shows the DSC curves of the PLA, epoxy, and PLA blend with $0.5-20 \%$ epoxy. The $T_{g}$ and $T_{m}$ of PLA were $60^{\circ} \mathrm{C}$ and $166^{\circ} \mathrm{C}$ and tended to decrease with increasing epoxy content owing to small crystal sizes [37] and partial miscibility between the epoxy and PLA blends, respectively [38]. The decrease in $T_{g}$ indicated that the epoxy acts as a plasticizer for the PLA. Large exothermic peak of the PLA/epoxy blends indicated to recrystallization during second heating scan of DSC measurement, which presented large endothermic peak of recrystallization at $110-135^{\circ} \mathrm{C}$. This recrystallization was not observed in pure PLA. 

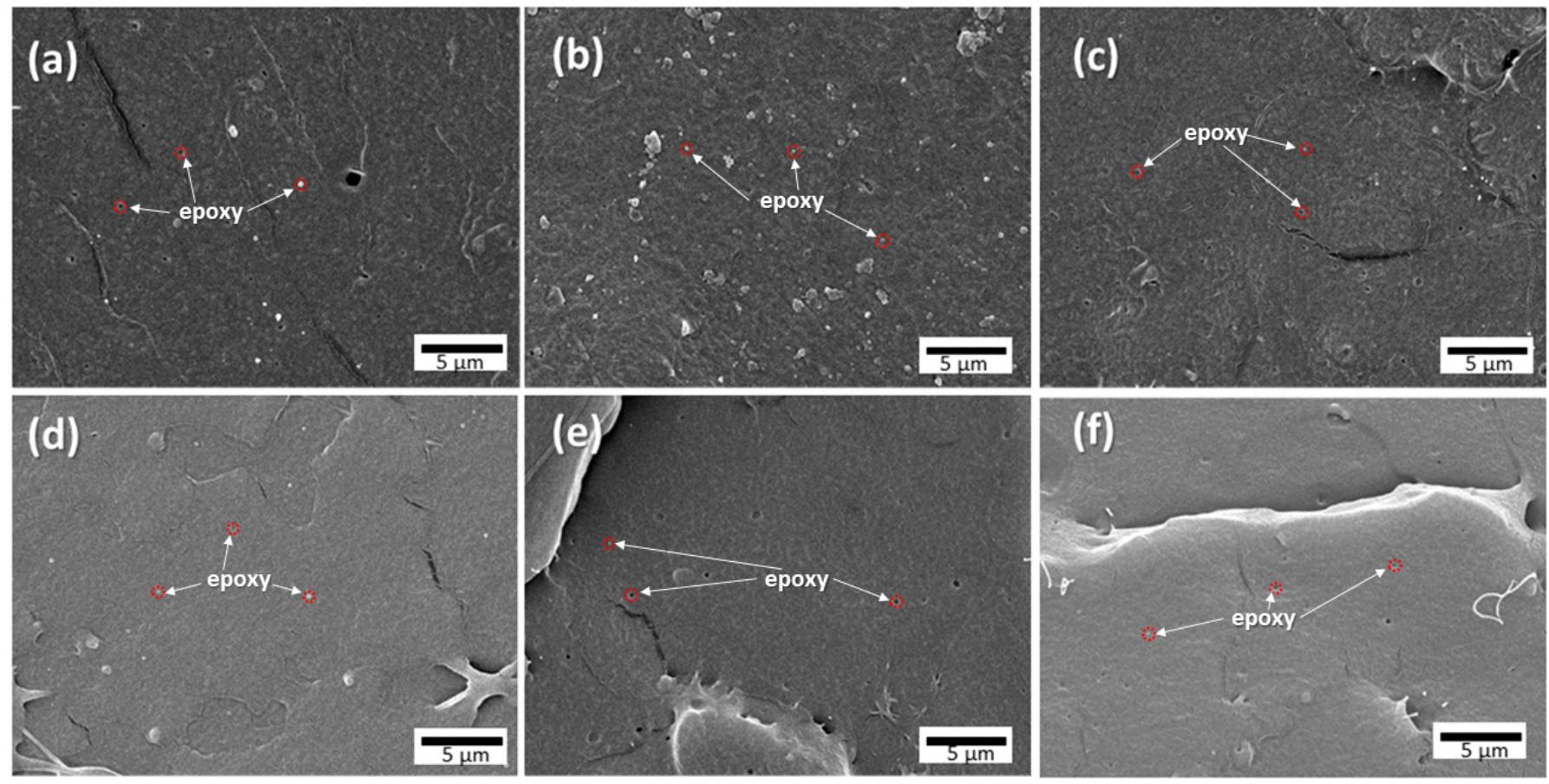

Figure 2. SEM fracture surface images of (a) PLA/epoxy0.5, (b) PLA/epoxy1, (c) PLA/Epoxy2, (d) PLA/epoxy5, (e) PLA/Epoxy10, and (f) PLA/Epoxy20.

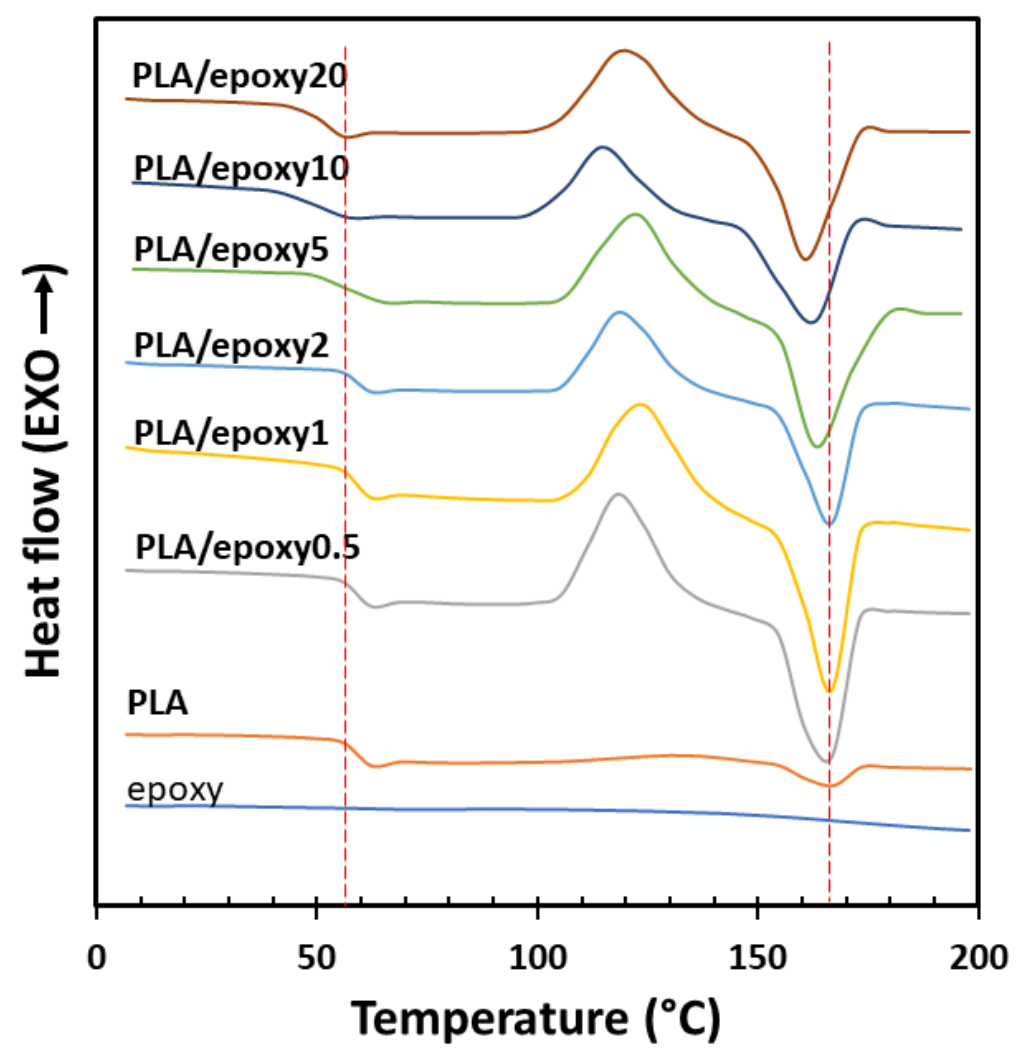

Figure 3. The second scan DSC curves of epoxy, PLA, and the PLA blend with 0.5-20\% epoxy.

The addition of the epoxy led to an increase in the chain length and reduced the mobility of the PLA chain [39]. The PLA crosslinked structure prevented the formation of inter- and intramolecular interactions of PLA crystallinity [40]; this resulted in the low crystallinity $(0.6-3.6 \%)$ of the blends. The epoxy reaction reduced the number of PLA chain 
terminals in the structure and prevented the formation of nuclei as well as the growth of the crystals $[29,41]$.

\subsection{Vicat Softening Temperature (VST)}

The VST test was used to determine the thermal stability based on the heat distortion temperature. The VST of PLA and the PLA blend with $0.5-20 \%$ epoxy resin are depicted in Figure 4 . The VST of the neat PLA was $59^{\circ} \mathrm{C}$, and when $0.5-2 \%$ epoxy was added, the VST showed an increasing trend to $64.6^{\circ} \mathrm{C}$. The VST of the PLA/epoxy 20 was reduced to $55.7^{\circ} \mathrm{C}$. The increased VST of the PLA/epoxy2 blend was due to the network structure of PLA, that was a result of the crosslinking reaction. Improvement of the VST due to internal crosslinking has been previously reported [42]. The decreased VST in the PLA blend with $5-20 \%$ epoxy indicated an excessive amount of epoxy and the crosslinking density inside PLA that reduced the crystal formation of the PLA. Thermal stability improvement due to a crosslinking structure and crystal formation has been previously reported [43].

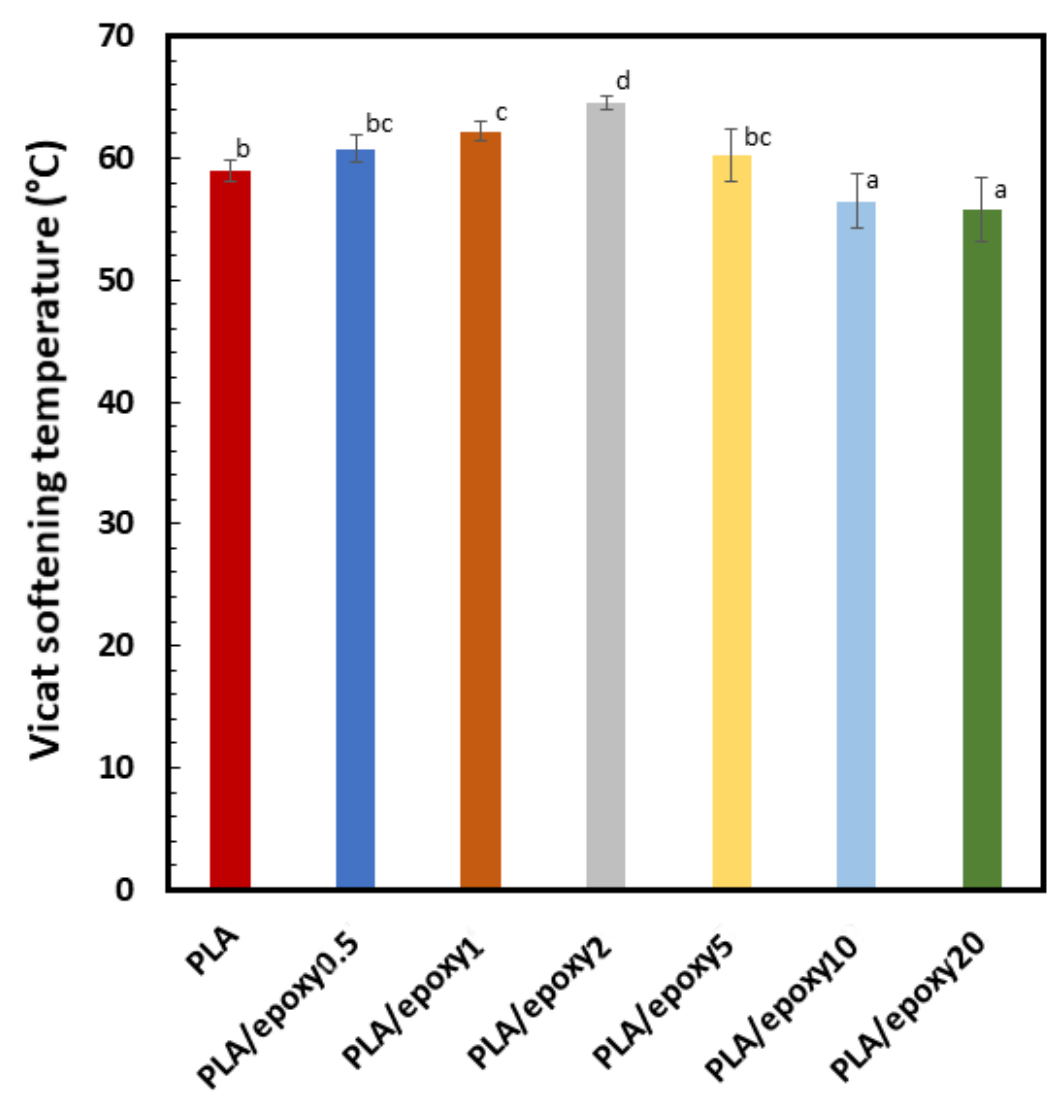

Figure 4. The Vicat softening temperature of PLA and the PLA blend with $0.5-20 \%$ epoxy. The mean values indicate by the different lowercase letters differ significantly $(p<0.05)$.

\subsection{Reaction Mechanism}

Figure 5 shows the ${ }^{13} \mathrm{C}$ NMR spectra of the PLA, epoxy, and the PLA/epoxy20 blend. The epoxy showed peaks of $-\mathrm{CH}_{3}$ (bisphenol A) at 30.7, oxirane ring carbons at 43.9 and 49.7 ppm, and bisphenol A carbons at 41.2, 68.0, 113.6, 127.3, 143.1, and 156.0 ppm [44]. Neat PLA showed peaks at $16.7\left(-\mathrm{CH}_{3}\right), 69.1$ (methylene carbon), and $169.70 \mathrm{ppm}(-\mathrm{C}=\mathrm{O})$ [45]. The ${ }^{13} \mathrm{C}$ NMR spectra of the PLA/epoxy blends showed the characteristic peaks of PLA and epoxy resin at the same position as that of neat epoxy and PLA. New peaks were observed at 21 and $67 \mathrm{ppm}$, corresponding to $\mathrm{C} 10$ and C11, respectively. Figure 6 shows the ${ }^{1} \mathrm{H}$ NMR spectra of PLA, epoxy, and the PLA/epoxy20 blend. Epoxy showed peaks $-\mathrm{CH}_{3}$ of bisphenol $\mathrm{A}$ at $1.6 \mathrm{ppm}(\mathrm{b}),-\mathrm{CH}_{2}$ of oxirane ring at 2.6 and $2.8 \mathrm{ppm}(\mathrm{c}),-\mathrm{CH}$ of oxirane ring at $3.29 \mathrm{ppm}(\mathrm{d}),-\mathrm{CH}_{2}$ at 3.9 and $4.29 \mathrm{ppm}(\mathrm{e})$, and aromatic protons of bisphenol $\mathrm{A}$ at 6.8 and $7.1 \mathrm{ppm}$ [44]. Neat PLA showed peaks at $1.6\left(\mathrm{a},-\mathrm{CH}_{3}\right)$ and $5.1 \mathrm{ppm}(\mathrm{b},-\mathrm{CH})$. The 
${ }^{1} \mathrm{H}$ NMR spectra of the PLA/epoxy blend showed characteristic peaks of $-\mathrm{CH}_{3}(1.6)$ and $-\mathrm{CH}(5.1)$ at the same position as that of neat PLA. Furthermore, the ${ }^{1} \mathrm{H}$ epoxy peaks of bisphenol A $(1.6,6.8$, and 7.1) shifted to lower positions, while the peaks of the oxirane ring $(2.6,2.8,3.29,3.9$, and 4.29) shifted to higher positions. New peaks were observed at 2.57 and 3.40 which indicated $\mathrm{H} 7$ and H6, respectively. The shifting of bisphenol A and the oxirane ring, and the appearance of two new peaks, confirmed the reaction between PLA and the epoxy. This also suggested a reaction between the epoxy groups of the epoxy resin and the - $\mathrm{COOH}$ end groups of PLA (Figure 6c). Previous studies have reported on the reaction between epoxy groups and $-\mathrm{COOH}$ groups $[46,47]$. This reaction improved the tensile properties, toughness, morphology, and thermal properties of PLA.

(a)<smiles>CC(O)OC(=O)C(C)(C)C(=O)O</smiles>

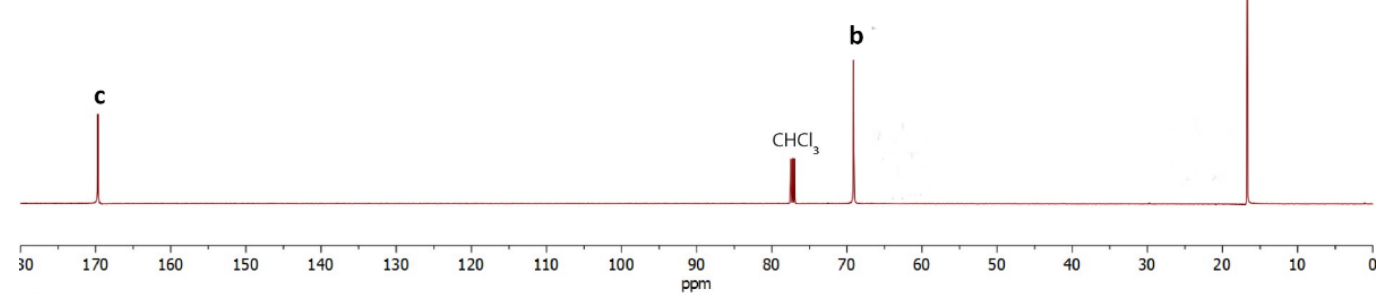

(b)
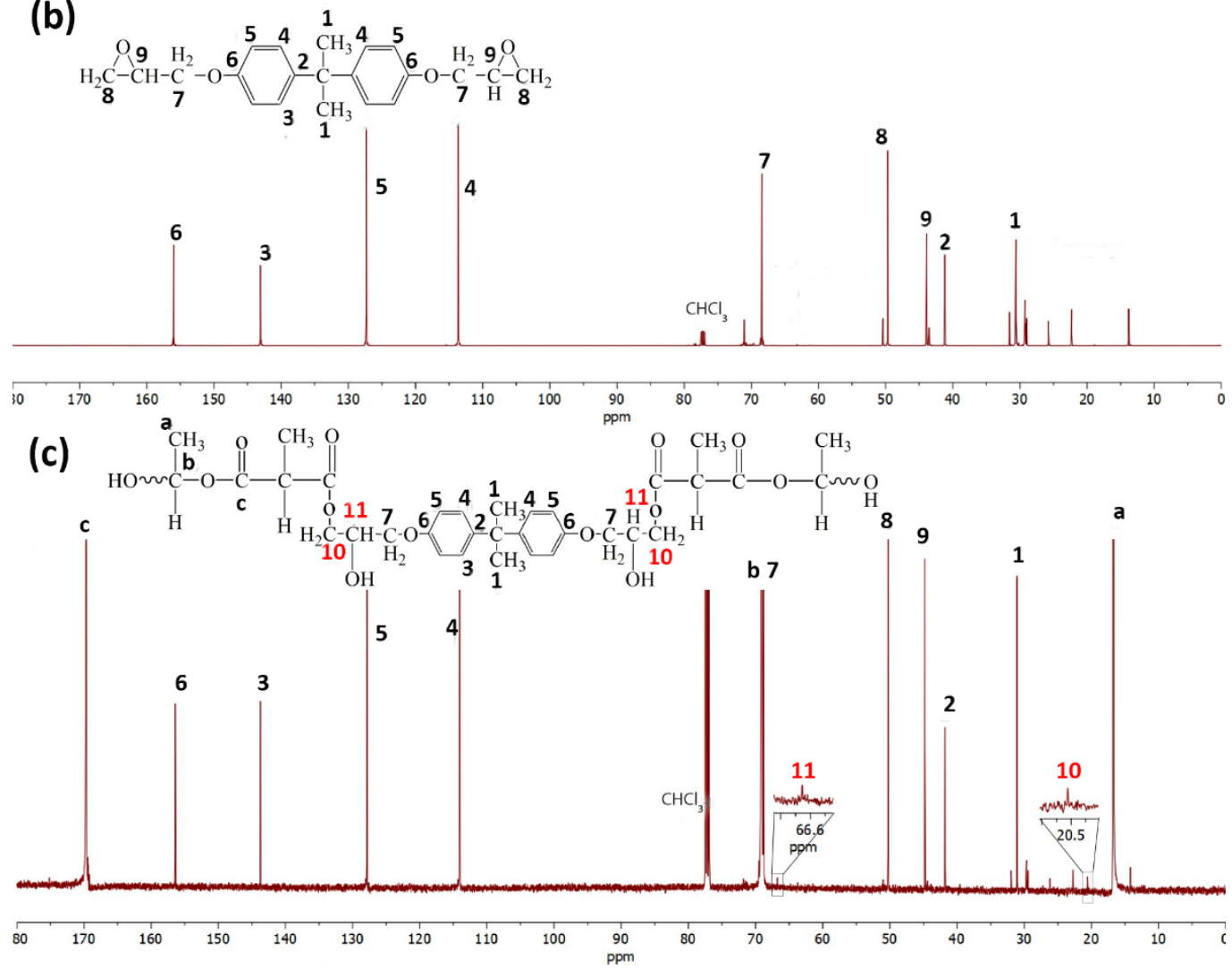

Figure 5. ${ }^{13} \mathrm{C}$ NMR spectra and structures of (a) neat PLA, (b) epoxy, and (c) the PLA/epoxy20 blend. 
(a)<smiles>CC(O)OC(=O)C(C)C(=O)O</smiles>
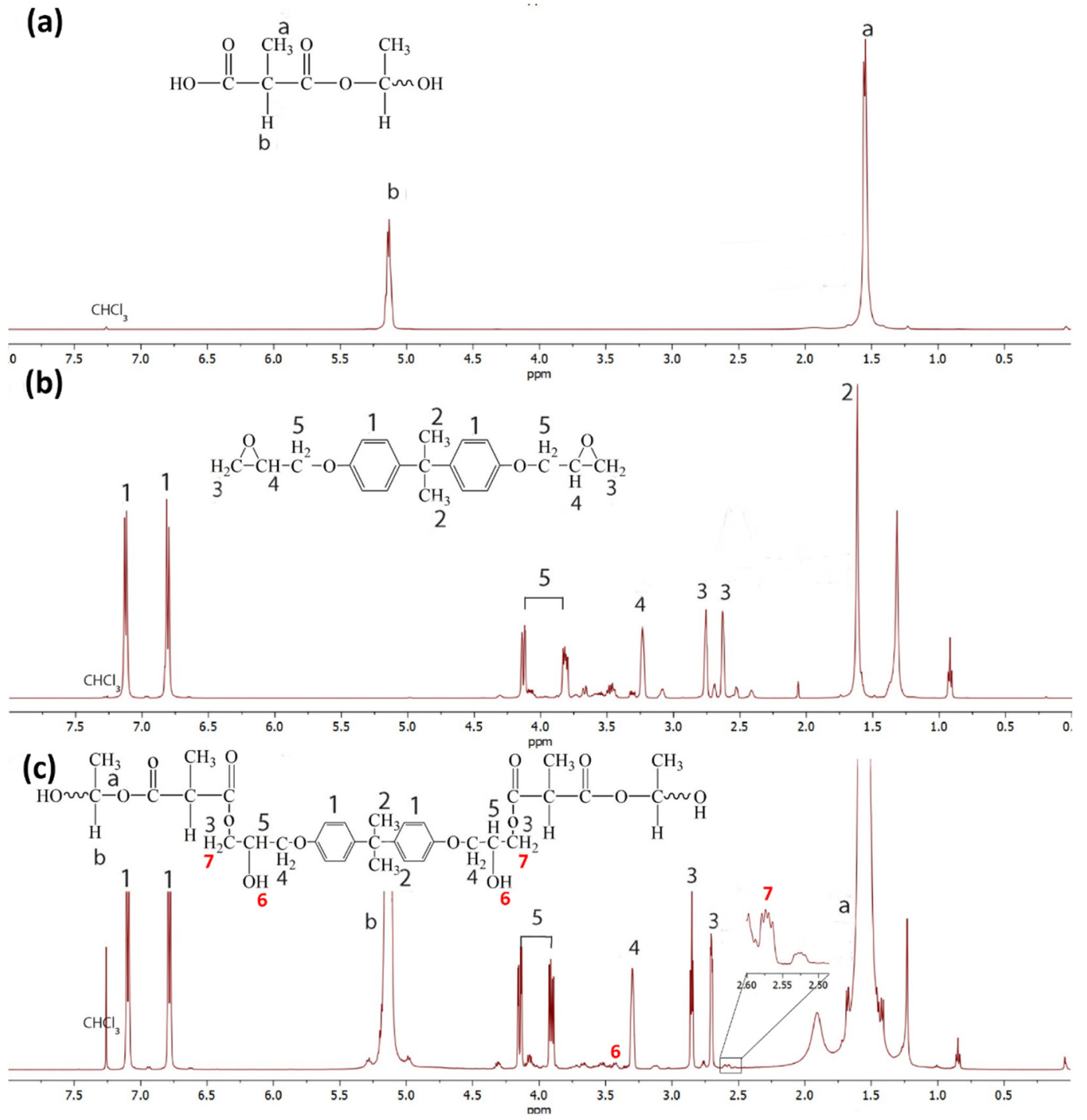

Figure 6. ${ }^{1} \mathrm{H}$ NMR spectra and structures of (a) neat PLA, (b) epoxy, and (c) the PLA/epoxy20 blend.

\section{Conclusions}

Epoxy resin was successfully blended with PLA to improve the mechanical properties and reaction mechanism of the blends. The maximum tensile strength of PLA was improved from $57.5 \mathrm{MPa}$ (neat PLA) to $66.9 \mathrm{MPa}$ with $0.5 \%$ epoxy, whereas the elongation at break showed a significant increase with $20 \%$ epoxy. Morphology of the PLA/epoxy blends showed nanoparticles dispersed in the PLA matrix, while a smooth fracture surface of the $5-10 \%$ PLA/epoxy blends was observed due to the high interfacial adhesion between PLA and epoxy. The $T_{m}$ and $T_{g}$ of the PLA/epoxy blends decreased with increasing epoxy content, owing to the nucleating effect of small epoxy particle sizes, and the partial miscibility between PLA and epoxy acting as a plasticizer, respectively. The VST of PLA increased with $2 \%$ epoxy, while an excessive amount of epoxy reduced the VST due to reduced crystal formation. NMR results confirmed the reaction between the $-\mathrm{COOH}$ groups of PLA and the epoxy groups of the epoxy resin. This reaction improved the mechanical properties, toughness, morphology, and thermal properties of the blends, additionally resulting in high optical transparency. The PLA/epoxy blends also contained unreacted epoxy groups that could react with other reactive functional groups for reactive blending as a compatibilizer. PLA/epoxy can be applied for packaging, medical, and agriculture applications. 
Author Contributions: Investigation, data curation and writing-original draft preparation, K.K.; investigation, N.T. and T.K.; visualization and writing-review and editing, P.R., N.L., Y.P., D.R., W.R. and S.R.S.; Conceptualization, writing-original draft preparation, project administration, funding acquisition and writing-review and editing, K.J. All authors have read and agreed to the published version of the manuscript.

Funding: This research was supported by the Program Management Unit for Human Resources \& Institutional Development, Research and Innovation, Office of National Higher Education Science Research and Innovation Policy Council (NXPO) [Grant Number B16F640001]. This research was partially supported by the Chiang Mai University.

Institutional Review Board Statement: Not applicable.

Informed Consent Statement: Not applicable.

Data Availability Statement: The data presented in this study are available on request from the corresponding author.

Acknowledgments: The authors gratefully acknowledge the Faculty of Agro-Industry, Chiang Mai University, for their support.

Conflicts of Interest: The authors declare no competing interests.

$\begin{array}{ll}\text { Abbreviations } \\ \text { PLA } & \text { polylactic acid } \\ \text { PBS } & \text { polybutylene succinate } \\ \text { TPS } & \text { thermoplastic starch } \\ \text { SEM } & \text { scanning electron microscopy } \\ \text { DSC } & \text { differential scanning calorimetry } \\ T_{m} & \text { melting temperature } \\ T_{g} & \text { glass transition temperature } \\ \text { NMR } & \text { nuclear magnetic resonance } \\ \text { CDCL3 } & \text { chloroform solvent }\end{array}$

\section{References}

1. Gregor-Svetec, D.; Leskovšek, M.; Leskovar, B.; Elesini, U.S.; Leskovar, B.; Elesini, U.S.; Vrabič-Brodnjak, U. Analysis of PLA composite filaments reinforced with lignin and polymerised-lignin-treated NFC. Polymers 2021, 13, 2174. [CrossRef]

2. Jantanasakulwong, K.; Rohindra, D.; Mori, K.; Kuboyama, K.; Ougizawa, T. Thermoplastic elastomer by reactive blending of poly(butylene succinate) with ethylene-propylene-diene terpolymer and ethylene-1-butene rubbers. J. Elastomers Plast. 2015, 47, 215-231. [CrossRef]

3. Jumaidin, R.; Diah, N.A.; IIyas, R.A.; Alamjuri, R.H.; Yusof, F.A.M. Processing and characterization of banana leaf fibre reinforced thermoplastic cassava starch composites. Polymers 2021, 13, 1420. [CrossRef] [PubMed]

4. Malyszek, Z.; Lewandowicz, J.; Thanh-Blicharz, J.L.; Walkowiak, K.; Kowalczewski, P.L.; Baranowska, H.M. Water behavior of emulsions stabilized by modified potato starch. Polymers 2021, 13, 2200. [CrossRef] [PubMed]

5. Surin, S.; You, S.; Seesuriyachan, P.; Muangrat, R.; Wangtueai, S.; Jambrak, A.R.; Phongthai, S.; Jantanasakulwong, K.; Chaiyaso, T.; Phimolsiripol, Y. Optimization of ultrasonic-assisted extraction of polysaccharides from purple glutinous rice bran (Oryza sativa L.) and their antioxidant activities. Sci. Rep. 2020, 10, 10410. [CrossRef] [PubMed]

6. Rachtanapun, P.; Klunklin, W.; Jantrawut, P.; Leksawasdi, N.; Jantanasakulwong, K.; Phimolsiripol, Y.; Seesuriyachan, P.; Chaiyaso, T.; Ruksiriwanich, W.; Phongthai, S.; et al. Effect of monochloroacetic acid on properties of carboxymethyl bacterial cellulose powder and film from nata de coco. Polymers 2021, 13, 488. [CrossRef] [PubMed]

7. Doan, C.T.; Chen, C.L.; Nguyen, V.B.; Tran, T.N.; Nguyen, A.D.; Wang, S.L. Conversion of pectin-containing by-products to pectinases by Bacillus amyloliquefaciens and its applications on hydrolyzing banana pells for prebiotics production. Polymers 2021, 13, 1483. [CrossRef] [PubMed]

8. Wongkaew, M.; Sommano, S.R.; Tangpao, T.; Rachtanapun, P.; Jantanasakulwong, K. Mango peel pectin by microwave-assisted extraction and its use as fat replacement in dried Chinese sausage. Foods 2020, 9, 450. [CrossRef]

9. Qi, X.; Ren, Y.; Wang, X. New advances in the biodegradation of Poly(lactic) acid. Int. Biodeterior. Biodegrad. 2017, 117, 215-223. [CrossRef]

10. Thomas, R.; Yumei, D.; Yuelong, H.; Le, Y.; Moldenaers, P.; Weimin, Y.; Czigany, T.; Thomas, S. Miscibility, morphology, thermal, and mechanical properties of a DGEBA based epoxy resin toughened with a liquid rubber. Polymer 2008, 49, 278-294. [CrossRef] 
11. Lee, J.; McCarthy, S. Biodegradable poly(lactic acid) blends with chemically modified polyhydroxyoctanoate through chain extension. J. Polym. Environ. 2009, 17, 240. [CrossRef]

12. Garlotta, D. A literature review of poly(lactic acid). J. Polym. Environ. 2001, 9, 63-84. [CrossRef]

13. Farah, S.; Anderson, D.G.; Langer, R. Physical and mechanical properties of PLA, and their functions in widespread applicationsComprehensive review. Adv. Drug Deliv. Rev. 2016, 107, 367-392. [CrossRef] [PubMed]

14. Jantanasakulwong, K.; Kobayashi, Y.; Kuboyama, K.; Ougizawa, T. Thermoplastic vulcanizate based on poly(lactic acid) and acrylic rubber blended with ethylene ionomer. J. Macromol. Sci. Phys. Part B 2016, 55, 1068-1085. [CrossRef]

15. Tokiwa, Y.; Calabia, B.P. Biodegradability and biodegradation of poly(lactide). Appl. Microbiol. Biotechnol. 2006, 72, $244-251$. [CrossRef] [PubMed]

16. Zhao, X.; Hu, H.; Wang, X.; Yu, X.; Zhou, W.; Peng, S. Super tough poly(lactic acid) blends: A comprehensive review. RSC Adv. 2020, 10, 13316-13368. [CrossRef]

17. Su, S.; Kopitzky, R.; Tolga, S.; Kabasci, S. Polylactide (PLA) and its blends with poly(butylene succinate) (PBS): A brief review. Polymers 2019, 11, 1193. [CrossRef] [PubMed]

18. Chavalitpanya, K.; Phattanarudee, S. Poly(lactic acid)/Polycaprolactone Blends Compatibilized with Block Copolymer. Energy Procedia 2013, 34, 542-548. [CrossRef]

19. Jantanasakulwong, K.; Homsaard, N.; Phengchan, P.; Rachtanapun, P.; Leksawasdi, N.; Phimolsiripol, Y.; Techapun, C.; Jantrawut, P. Effect of dip coating polymer solutions on properties of thermoplastic cassava starch. Polymers 2019, 11, 1746. [CrossRef]

20. Verma, C.; Olasunkanmi, L.O.; Akpan, E.D.; Quraishi, M.A.; Dagdag, O.; Gouri, M.E.; Sherif, E.-S.M.; Ebenso, E.E. Epoxy resins as anticorrosive polymeric materials: A review. React. Funct. Polym. 2020, 156, 104741. [CrossRef]

21. Bucknall, C.B.; Gilbert, A.H. Toughening tetrafunctional epoxy resins using polyetherimide. Polymer 1989, 30, 213-217. [CrossRef]

22. Hourston, D.J.; Lane, J.M. The toughening of epoxy resins with thermoplastics: 1. Trifunctional epoxy resin-polyetherimide blends. Polymer 1992, 33, 1379-1383. [CrossRef]

23. Park, S.J.; Kim, H.C. Thermal stability and toughening of epoxy resin with polysulfone resin. J. Polym. Sci. Part B Polym. Phys. 2001, 39, 121-128. [CrossRef]

24. Silva, I.D.S.; Barros, J.J.P.; Albuquerque, A.; Jaques, N.G.; Fook, M.V.L.; Wellen, R.M.R. Insights into the curing kinetics of epoxy/PLA: Implications of the networking structure. Express Polym. Lett. 2020, 14, 1180-1196. [CrossRef]

25. Kodsangma, A.; Homsaard, N.; Nadon, S.; Rachtanapun, P.; Leksawasdi, N.; Phimolsiripol, Y.; Insomphun, C.; Seesuriyachan, P.; Chaiyaso, T.; Jantrawut, P.; et al. Effect of sodium benzoate and chlorhexidine gluconate on a biothermoplastic elastomer made from thermoplastic starch-chitosan blended with epoxidized natural rubber. Carbohydr. Polym. 2020, 242, 116421. [CrossRef]

26. $\mathrm{Hu}, \mathrm{L}$.; Vuillaume, P.Y. Chapter 7-Reactive compatibilization of polymer blends by coupling agents and interchange catalysts. In Compatibilization of Polymer Blends, 3rd ed.; Elsevier: Amsterdam, The Netherlands, 2020; pp. 205-248.

27. Choi, J.; Lim, S.; Kim, J.; Choe, C.R. Studies of an epoxy-compatibilized poly(phenylene sulfide)/polycarbonate blend. Polymer 1997, 38, 4401-4406. [CrossRef]

28. Chiou, K.C.; Chang, F.C. Reactive compatibilization of polyamide-6 (PA 6)/polybutylene terephthalate (PBT) blends by a multifunctional epoxy resin. J. Polym. Sci. Part B Polym. Phys. 2000, 38, 23-33. [CrossRef]

29. Liu, Z.-Y.; Weng, Y.-X.; Huang, Z.-G.; Wang, L.; Qiu, D.; Shao, S.-X. Effect of epoxy chain extender on the properties of polylactic acid. J. Appl. Mater. Sci. Eng. Res. 2019, 2,1-7.

30. Limsukon, W.; Auras, R.; Selke, S. Hydrolytic degradation and lifetime prediction of poly(lactic acid) modified with a multifunctional epoxy-based chain extender. Polym. Test. 2019, 80, 106108. [CrossRef]

31. Yu, X.; Wang, X.; Zhang, Z.; Peng, S.; Chen, H.; Zhao, X. High-performance fully bio-based poly(lactic acid)/polyamide11 (PLA/PA11) blends by reactive blending with multi functionalized epoxy. Polym. Test. 2019, 78, 105980. [CrossRef]

32. Corre, Y.-M.; Duchet, J.; Reignier, J.; Maazouz, A. Melt strengthening of poly (lactic acid) through reactive extrusion with epoxy-functionalized chains. Rheol. Acta 2011, 50, 613-629. [CrossRef]

33. Karkhanis, S.S.; Matuana, L.M. Extrusion blown films of poly(lactic acid) chain-extended with food grade multifunctional epoxies. Polym. Eng. Sci. 2019, 59, 2211-2219. [CrossRef]

34. Jia, S.; Yu, D.; Zhu, Y.; Wang, Z.; Chen, L.; Fu, L. Morphology, crystallization and thermal behaviors of PLA-based composite: Wonderful effects of hybrid GO/PEG via Dynamic impregnating. Polymers 2017, 9, 528. [CrossRef] [PubMed]

35. Semba, T.; Kitagawa, K.; Ishiaku, U.S.; Hamada, H. The Effect of Crosslinking on the Mechanical Properties of Polylactic Acid/Polycaprolactone Blends. J. Appl. Polym. Sci. 2006, 101, 1816-1825. [CrossRef]

36. Maruhashi, Y.; Iida, S. Transparency of polymer blends. Polym. Eng. Sci. 2001, 41, 1987-1995. [CrossRef]

37. Aumnate, C.; Rudolph, N.; Sarmadi, M. Recycling of polypropylene/polyethylene blends: Effect of chain structure on the crystallization behaviors. Polymers 2019, 11, 1456. [CrossRef]

38. Aid, S.; Eddhahak, A.; Ortega, Z.; Froelich, D.; Tcharkhtchi, A. Experimental study of the miscibility of ABS/PC polymer blends and investigation of the processing effect. J. Appl. Polym. Sci. 2017, 134, 44975. [CrossRef]

39. Bednarek, M.; Borska, K.; Kubisa, P. Crosslinking of polylactide by high energy irradiation and photo-curing. Molecules 2020, 25, 4919. [CrossRef] [PubMed]

40. Simis, K.S.; Bistolfi, A.; Bellare, A.; Pruitt, L.A. The combined effects of crosslinking and high crystallinity on the microstructural and mechanical properties of ultra high molecular weight polyethylene. Biomaterials 2006, 27, 1688-1694. [CrossRef] 
41. Zamponi, M.; Monkenbusch, M.; Willner, L.; Wischnewski, A.; Farago, B.; Richter, D. Contour length fluctuations in polymer melts: A direct molecular proof. Europhys. Lett. 2005, 72, 1039-1044. [CrossRef]

42. Garcia-Castaneda, C.; Benavides, R.; Martinez-Pardo, M.E.; Uribe, R.M.; Carrasco-Abrego, H.; Martinez, G. Crosslinking of rigid PVC by ionizing radiation to improve its thermal properties. Radiat. Phys. Chem. 2010, 79, 335-338. [CrossRef]

43. Xiang, H.X.; Zabihi, F.; Zhang, X.Z.; Zhu, M.F. The Crystallization, Melting Behaviors and Thermal Stability of Cross-linked Poly(3-hydroxybutyrate-co-3-hydroxyvalerate) by Octavinyloctasilasesquioxane. Chin. J. Polym. Sci. 2018, 36, 1353-1360. [CrossRef]

44. Ahmad, S.; Gupta, A.P.; Sharmin, E.; Alam, M.; Pandey, S.K. Synthesis, characterization and development of high performance siloxane-modified epoxy paints. Prog. Org. Coat. 2005, 54, 248-255. [CrossRef]

45. Klinkajorn, J.; Tanrattanakul, V. The effect of epoxide content on compatibility of poly(lactic acid)/epoxidized natural rubber blends. J. Appl. Polym. Sci. 2020, 137, 48996. [CrossRef]

46. Blank, W.J.; He, Z.A.; Picci, M. Catalysis of the epoxy-carboxyl reaction. J. Coat. Technol. 2002, 74, 33-41. [CrossRef]

47. Morancho, J.M.; Ramis, X.; Fernandez-Francos, X.; Konuray, O.; Salla, J.M.; Serra, A. Dual curing of an epoxy resin with dicarboxylic acids. J. Therm. Anal. Calorim. 2020, 142, 607-615. [CrossRef] 